\title{
Chryseoglobus frigidaquae gen. nov., sp. nov., a novel member of the family Microbacteriaceae
}

\author{
Keun Sik Baik, ${ }^{1}$ Seong Chan Park, ${ }^{1}$ Ho Jun Kim, ${ }^{1}$ Kang Hyun Lee ${ }^{2}$ \\ and Chi Nam Seong ${ }^{1}$ \\ ${ }^{1}$ Department of Biology, Sunchon National University, Suncheon 540-742, Republic of Korea \\ ${ }^{2}$ Biological Resource Center, Korea Research Institute of Bioscience and Biotechnology, 52 Oun- \\ dong, Yuseong, Daejeon 305-333, Republic of Korea
}

Correspondence

Chi Nam Seong scnu@scnu.ac.kr

\begin{abstract}
A motile, rod-shaped, yellow-pigmented bacterium, designated strain $\mathrm{CW}^{\top}{ }^{\top}$, was isolated from a water-cooling system in the Republic of Korea. Cells were Gram-stain-positive, aerobic, catalasepositive and oxidase-negative. Strain $\mathrm{CW}^{\top}{ }^{\top}$ formed slender rods with unusual bulbous protuberances. The major fatty acids were iso- $\mathrm{C}_{16: 1}(33.7 \%)$, anteiso- $\mathrm{C}_{15: 0}(27.2 \%)$, iso- $\mathrm{C}_{14: 0}$ $(13.3 \%)$ and $C_{16: 0}(10.8 \%)$. The cell-wall peptidoglycan was of type $B 2 \beta$, containing lysine as the diamino acid. The respiratory quinones were menaquinones with 12,13 and 14 isoprene units. A phylogenetic tree based on $16 \mathrm{~S}$ rRNA gene sequences showed that strain $\mathrm{CW} 1^{\top}$ formed an evolutionary lineage within the radiation enclosing members of the family Microbacteriaceae and was related to, but distant from, members of the genera Microcella and Yonghaparkia. On the basis of the evidence presented, strain $\mathrm{CW}_{1}{ }^{\top}$ is considered to represent a novel species of a new genus in the family Microbacteriaceae, for which the name Chryseoglobus frigidaquae gen. nov., sp. nov. is proposed. The type strain of Chryseoglobus frigidaquae is $\mathrm{CW}^{\top}{ }^{\top}\left(=\mathrm{KCTC} 13142^{\top}\right.$ $=\mathrm{JCM} 14730^{\top}$ ).
\end{abstract}

The family Microbacteriaceae (Park et al., 1993; Stackebrandt et al., 1997) comprises actinobacteria that are irregularly shaped, aerobic, non-motile, non-sporeforming and Gram-positive and have $\mathrm{G}+\mathrm{C}$-rich genomic DNA. At the time of writing, the family Microbacteriaceae comprised 31 recognized genera, members of which originated from natural and artificial habitats, such as distilled water, freshwater, groundwater, plants, seawater, sewage and soil (An et al., 2008; Evtushenko et al., 2000; Han et al., 2003; Männistö et al., 2000; Sheridan et al., 2003; Tiago et al., 2005, 2006; Vaz-Moreira et al., 2008; Yoon et al., 2006). Cell walls of microbacteria are characterized by the presence of diamino acids such as lysine, ornithine and diaminobutyric acid, the distribution of which is one of the key chemotaxonomic markers for generic differentiation (Schleifer \& Kandler, 1972). Menaquinones with 9-12 isoprene units (MK-9 to -12) are the predominant isoprenoid quinones, and straight or branched, saturated fatty acids constitute the major membrane lipid components (Jones \& Collins, 1986; Collins \& Bradbury, 1992). Some psychrophilic bacteria of the Microbacteriaceae, namely Frigoribacterium faeni and Cryobacterium psychrophilum, contain a certain amount of

The GenBank/EMBL/DDBJ accession number for the 16S rRNA gene sequence of strain $\mathrm{CW}^{\top}{ }^{\top}$ is EF373534.

A table giving the complete fatty acid profile of strain $\mathrm{CW}^{\top}{ }^{\top}$ is available as supplementary material with the online version of this paper. unsaturated fatty acids when grown at lower temperatures (Suzuki et al., 1997; Kämpfer et al., 2000). The cell-wall peptidoglycan is of type B sensu Schleifer \& Kandler (1972); no mycolic acids are found.

During the course of a study on the microbial diversity of a water-cooling system, a novel bacterium, designated strain $\mathrm{CW1}^{\mathrm{T}}$, was isolated and was the subject of a taxonomic investigation. On the basis of evidence from the present polyphasic study, strain $\mathrm{CW}^{\mathrm{T}}$ is considered to represent a novel species of a new genus in the family Microbacteriaceae.

Strain $\mathrm{CW}^{\mathrm{T}}$ was isolated from a cooled water sample from an oxygen-producing plant in the Republic of Korea during February 2005 by using the standard dilution plating technique. Isolation was achieved by using plate count agar (PCA; Difco) at $25{ }^{\circ} \mathrm{C}$ for 5 days. The isolate was routinely cultured on trypticase soy agar (TSA; Difco) and was maintained at $-80{ }^{\circ} \mathrm{C}$ as a suspension in trypticase soy broth (TSB; Difco) containing glycerol (20\%, w/v).

Bacterial DNA preparation and PCR amplification and sequencing of the $16 \mathrm{~S}$ rRNA gene were carried out as described by Chun \& Goodfellow (1995). The resultant 16S rRNA gene sequence of strain $\mathrm{CW}^{\mathrm{T}}$ was aligned manually against sequences obtained from the GenBank database. Phylogenetic trees were inferred from the regions available for all sequences (positions 22-1459 according to the 
Escherichia coli numbering system) by using the FitchMargoliash (Fitch \& Margoliash, 1967) and neighbourjoining (Saitou \& Nei, 1987) methods. Evolutionary distance matrices were generated according to Jukes \& Cantor (1969). The resultant neighbour-joining tree topology was evaluated by bootstrap analyses (Felsenstein, 1985) based on 1000 resamplings. Alignment and phylogenetic analyses were carried out by using the PHYDIT program (available at http://plaza.snu.ac.kr/ jchun/phydit/) and PAUP 4.0 (Swofford, 1998) as described by Chun et al. (2000).

Preliminary sequence comparison with $16 \mathrm{~S}$ rRNA gene sequences held in GenBank indicated that strain $\mathrm{CW}^{\mathrm{T}}$ was related closely to members of the family Microbacteriaceae. The newly determined sequence was then aligned manually against representatives of the family Microbacteriaceae. Strain $\mathrm{CW}^{\mathrm{T}}$ showed highest $16 \mathrm{~S}$ rRNA gene sequence similarity to Microcella putealis $\mathrm{CV}-2^{\mathrm{T}}$ (97.6\%), followed by Microcella alkaliphilia $\mathrm{AC}^{\mathrm{T}} \mathrm{r}^{\mathrm{T}}(97.0 \%)$ and Yonghaparkia alkaliphilia KSL-113 ${ }^{\mathrm{T}}(96.6 \%)$. To elucidate the phylogenetic relationship between the novel isolate and other species within the family Microbacteriaceae, phylogenetic trees were constructed by using two tree-making algorithms. The neighbour-joining tree (Fig. 1) showed that strain
$\mathrm{CW} 1^{\mathrm{T}}$ formed a distinct branch with the clade comprising the genera Microcella and Yonghaparkia; this topology was also recovered in the Fitch-Margoliash tree (not shown). On the basis of $16 \mathrm{~S}$ rRNA gene sequence similarity data and the results of phylogenetic analysis, it is clear that strain $\mathrm{CW} 1^{\mathrm{T}}$ represents a novel species of a new genus within the family Microbacteriaceae.

Growth on various standard bacteriological media was tested by using nutrient agar (NA; Difco), TSA and R2A agar (Difco) according to the manufacturer's instructions. Cells grown at $30{ }^{\circ} \mathrm{C}$ for 2 days were observed via scanning electron microscopy (S-4800; Hitachi). Cells of strain $\mathrm{CW}^{\mathrm{T}}$ grown on TSA at $30{ }^{\circ} \mathrm{C}$ for 3 days were used for physiological and biochemical tests. Motility was examined by observing cells grown in wet mounts by using phasecontrast microscopy (TMS-F; Nikon). Growth at various $\mathrm{NaCl}$ concentrations $(0-10 \%, \mathrm{w} / \mathrm{v}$, at increments of $1.0 \%)$ was investigated in TSB prepared according to the formula of the Difco medium except that no $\mathrm{NaCl}$ was used. The $\mathrm{pH}$ range for growth was determined in TSB that was adjusted to $\mathrm{pH} 4-12$ (in increments of $1 \mathrm{pH}$ unit) by the addition of $\mathrm{HCl}$ or $\mathrm{NaOH}$. Growth temperature $\left(4-42{ }^{\circ} \mathrm{C}\right)$ and growth in an anaerobic chamber $\left(\mathrm{CO}_{2} / \mathrm{H}_{2} / \mathrm{N}_{2}\right.$, 10:10:80; Sheldon Manufacturing) were checked by

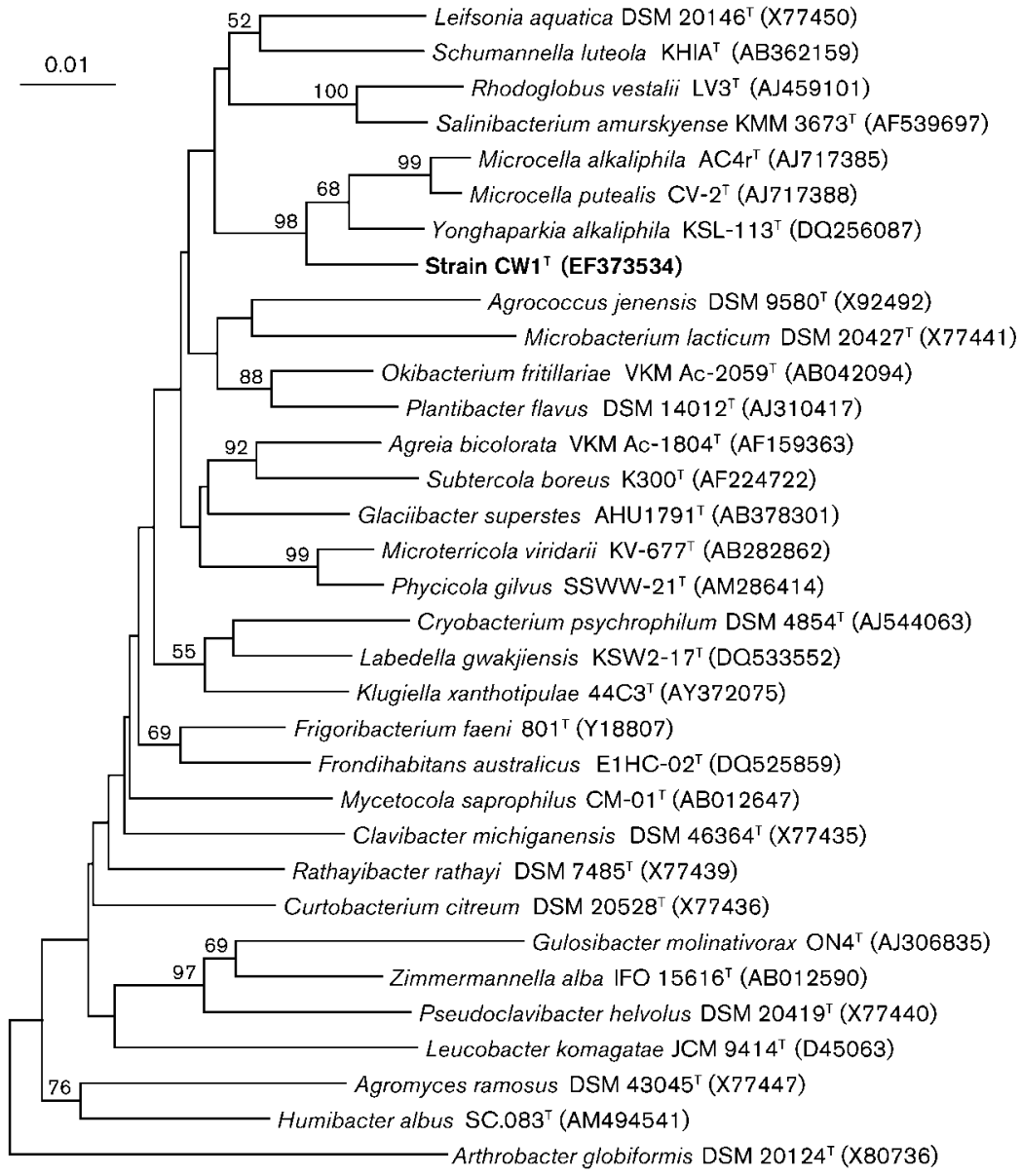

Fig. 1. Neighbour-joining tree based on nearly complete 16S rRNA gene sequences showing the relationship between strain $\mathrm{CW}_{1}{ }^{\top}$ and members of the family Microbacteriaceae. Numbers at nodes are levels of bootstrap support (percentages) based on neighbourjoining analyses of 1000 resampled datasets. Bar, 0.01 substitutions per nucleotide position. 
incubation on TSA for up to 1 week. Catalase and oxidase activities were determined by using $3 \%(\mathrm{v} / \mathrm{v})$ hydrogen peroxide and Kovács' reagent (Kovács, 1956), respectively. Nitrate reduction was tested on nitrate broth containing $0.2 \% \mathrm{KNO}_{3}$ (Skerman, 1967). Citrate utilization was tested on Simmons' citrate agar (Sigma). Indole production was determined with Kovács' indole reagent in $1 \%$ tryptone broth. $\mathrm{H}_{2} \mathrm{~S}$ production was determined on Kligler iron agar (Difco). The absorption spectrum of pigments extracted with ethanol (Gosink et al., 1998) was analysed by using an Ultrospec 2100 pro UV/visible spectrophotometer (Amersham Biosciences). The presence of flexirubin-type pigments was examined as described by Bernardet et al. (2002). Other physiological and biochemical tests were performed by using the API 20E, API 20NE and API 50CH systems (bioMérieux). Enzyme activities were tested by using an API ZYM kit (bioMérieux) following the manufacturer's instructions. Antibiotic resistance was determined with the disc diffusion method by using commercial antibiotic-impregnated discs (BBL Becton Dickinson). Results were interpreted according to guidelines of the Clinical and Laboratory Standards Institute (CLSI, 2003).

Strain $\mathrm{CW}^{\mathrm{T}}$ formed smooth, raised (convex), entire, translucent, non-slimy, yellowish colonies (approximately $1 \mathrm{~mm}$ in diameter) after 3 days at $30{ }^{\circ} \mathrm{C}(\mathrm{pH} 7)$ on TSA. Strain $\mathrm{CW}^{\mathrm{T}}$ grew aerobically between 20 and $40{ }^{\circ} \mathrm{C}$ (optimally at $30{ }^{\circ} \mathrm{C}$ ) and between $\mathrm{pH} 6$ and 11 (optimally at $\mathrm{pH} 7-8$ ). Strain $\mathrm{CW} 1^{\mathrm{T}}$ tolerated up to $3 \% \mathrm{NaCl}$, but optimal growth was observed in the absence of $\mathrm{NaCl}$. Strain $\mathrm{CW} 1^{\mathrm{T}}$ produced diffusible yellow pigments. Growth did not occur on MacConkey agar. Microscopic observations showed that cells of the novel strain were motile, Gram-positive, non-spore-forming, pleomorphic, short, slender rods, about $0.15-0.2 \mu \mathrm{m}$ wide and $1.5-2.0 \mu \mathrm{m}$ long. The cells frequently appeared swollen at the ends or in the middle, as is often observed for members of the genus Rhodoglobus. Scanning electron microscopy revealed extremely slender cells with enlarged, bulbous protuberances that were approximately $0.6 \mu \mathrm{m}$ in diameter (Fig. 2). Some of the cells were slightly curved, but lacked the typical fragmented shapes often seen with members of the genus Arthrobacter. Strain $\mathrm{CW}^{\mathrm{T}}$ had morphological features consistent with its placement within the family Microbacteriaceae. The detailed results of physiological and biochemical analyses are given in the species description, and Table 1 provides several phenotypic characteristics that can be used to separate strain $\mathrm{CW} 1^{\mathrm{T}}$ from phylogenetically related genera.

Cellular fatty acids of strain $\mathrm{CW}^{\mathrm{T}}$ grown on TSA for 2 days at $30{ }^{\circ} \mathrm{C}$ were prepared (in duplicate) and were analysed as methyl esters by GLC according to the instructions of the Microbial Identification System (MIDI, 1999). Phospholipids were analysed by using standard procedures (Minnikin et al., 1984). Quantitative analysis of amino acids was performed after derivatization by GC and GC/MS (320-MS Quadrupole GC/MS; Varian) according to MacKenzie (1987). Determination of the

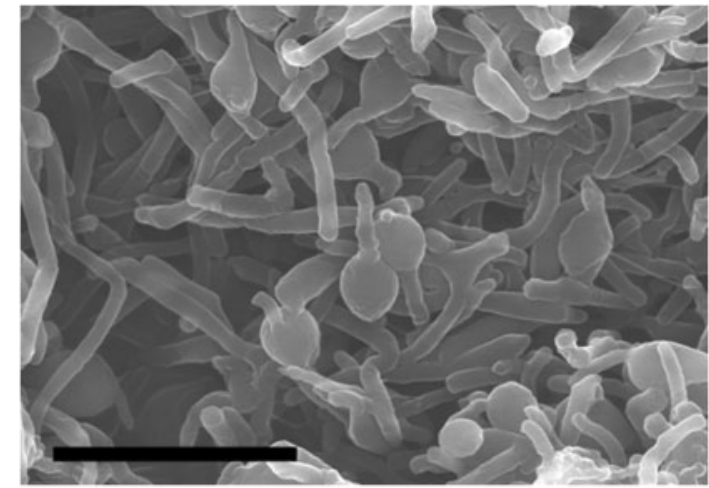

Fig. 2. Scanning electron micrograph of cells of strain $\mathrm{CW}^{1}{ }^{\top}$. Cells were grown on TSA at $25{ }^{\circ} \mathrm{C}$ for 2 days. Bar, $2 \mu \mathrm{m}$.

peptidoglycan structure of strain $\mathrm{CW}^{\mathrm{T}}$ was carried out as described by Schleifer (1985) and Schleifer \& Kandler (1972) with the modification that TLC on cellulose was applied instead of paper chromatography. The cell-wall acyl type was determined by the method of Uchida et al. (1999). Respiratory quinones were extracted (from $300 \mathrm{mg}$ freeze-dried cells) and purified according to the method of Minnikin et al. (1984) and were analysed by HPLC as described by Kroppenstedt (1985). The G + C content of the genomic DNA was calculated by using the formula described by Mandel et al. (1970). The DNA sample was prepared in duplicate and the $\mathrm{G}+\mathrm{C}$ content was determined by thermal denaturation (Marmur \& Doty, 1962).

Major fatty acids of strain $\mathrm{CW1}^{\mathrm{T}}$ were iso- $\mathrm{C}_{16: 0}(33.7 \%)$, anteiso- $\mathrm{C}_{15: 0}(27.2 \%)$, iso- $\mathrm{C}_{14: 0}(13.3 \%)$ and $\mathrm{C}_{16: 0}$ $(10.8 \%)$; the complete fatty acid profile is given in Supplementary Table S1, available in IJSEM Online. Straight-chain saturated, anteiso-methyl-branched and iso-methyl-branched fatty acids were the predominant components ( $>10 \%$ of the total fatty acids), as with most members of the family Microbacteriaceae, except the genera Microcella, Mycetocola, Subtercola and Yonghaparkia. The major polar lipids detected in strain $\mathrm{CW}^{\mathrm{T}}$ were diphosphatidylglycerol, phosphatidylglycerol and an unidentified glycolipid. The total hydrolysate $\left(4 \mathrm{M} \mathrm{HCl}, 16 \mathrm{~h}, 100{ }^{\circ} \mathrm{C}\right)$ of the peptidoglycan contained the amino acids lysine, glutamic acid, homoserine (Hsr), alanine and glycine in a molar ratio of approximately $1.0: 1.0: 0.6: 0.8: 1.4$. The partial hydrolysate $\left(4 \mathrm{M} \mathrm{HCl}, 0.75 \mathrm{~h}, 100{ }^{\circ} \mathrm{C}\right)$ of the peptidoglycan contained (in addition to the amino acids) the peptides Gly $\rightarrow$ D-Glu and Lys $\rightarrow$ D-Ala. From these data it was concluded that strain $\mathrm{CW}^{\mathrm{T}}$ has peptidoglycan of type B2 $\beta$ (\{Gly\} [L-Hsr] D-Glu $\rightarrow$ D-Lys, where \{\} and [ ] indicate positions 1 and 3 of the peptide subunit). This peptidoglycan structure has previously been reported only for Frigoribacterium faeni (Kämpfer et al., 2000). The respiratory quinones found in strain $\mathrm{CW}^{\mathrm{T}}$ were menaquinones MK-13 (44\%), MK-14 (35\%) and MK-12 
Table 1. Phenotypic characteristics that differentiate strain $\mathrm{CW} 1^{\top}$ from its phylogenetic neighbours in the family Microbacteriaceae

Data for reference genera were taken from An et al. (2008), Evtushenko et al. (2000), Han et al. (2003), Reddy et al. (2008), Sheridan et al. (2003), Tiago et al. (2005, 2006), Yoon et al. (2006) and the present study. +, Positive; -, negative; v, variable; NR, not reported; tr, trace amount.

\begin{tabular}{|c|c|c|c|c|c|c|c|}
\hline Characteristic & Strain $\mathrm{CW1}^{\mathrm{T}}$ & Microcella & Yonghaparkia & Salinibacterium & Rhodoglobus & Leifsonia & Schumannella \\
\hline Colony colour & Yellow & Yellow & Yellow & NR & Red & Yellow or white & Yellow \\
\hline Cell shape & $\begin{array}{c}\text { Slender rods, } \\
\text { swollen }\end{array}$ & Slender rods & Slender rods & Irregular rods & $\begin{array}{l}\text { Pleomorphic, } \\
\text { short, slender } \\
\text { rods, swollen }\end{array}$ & $\begin{array}{l}\text { Irregular rods or } \\
\text { filaments }\end{array}$ & Short rods \\
\hline Motility & + & - & - & - & + & $\mathrm{V}$ & - \\
\hline $\begin{array}{l}\text { Growth } \\
\text { temperature } \\
\text { range }\left({ }^{\circ} \mathrm{C}\right)\end{array}$ & $20-40$ & $15-40$ & $10-37$ & $4-37$ & -2 to 21 & $0-42$ & $8-35$ \\
\hline $\begin{array}{l}\text { Cell-wall diamino } \\
\operatorname{acid}(\mathrm{s})^{*}\end{array}$ & Lys & Lys, Orn & $\mathrm{DAB}$ & Lys, Orn & Orn & $\mathrm{DAB}$ & DAB \\
\hline $\begin{array}{l}\text { Presence of } \\
\text { homoserine }\end{array}$ & + & - & - & - & $\operatorname{tr}$ & - & - \\
\hline $\begin{array}{l}\text { Major fatty acids } \\
(>10 \% \text { of total })\end{array}$ & $\begin{array}{l}\text { i- } C_{16: 0}, \text { ai- } C_{15: 0} \\
\quad \text { i- } C_{14: 0}, C_{16: 0}\end{array}$ & $\begin{array}{l}\mathrm{i}-\mathrm{C}_{16: 0}, \text { ai- } \mathrm{C}_{15: 0}, \\
\mathrm{i}-\mathrm{C}_{14: 0}, \mathrm{i}-\mathrm{C}_{15: 0}\end{array}$ & $\begin{array}{c}\text { ai- } \mathrm{C}_{15: 0}, \mathrm{i}^{-} \\
\mathrm{C}_{16: 0}, \text { ai- } \mathrm{C}_{17: 0}\end{array}$ & $\begin{array}{l}\text { ai- } \mathrm{C}_{15: 0}, \mathrm{i}- \\
\mathrm{C}_{16: 0}, \mathrm{i}-\mathrm{C}_{14: 0}\end{array}$ & $\begin{array}{l}\text { ai- } C_{15: 0}, \text { ai- } \\
C_{17: 0}, i-C_{16: 0}\end{array}$ & $\begin{array}{c}\text { ai- } C_{15: 0}, \\
\text { ai- } C_{17: 0}, \text { i- } C_{16: 0}\end{array}$ & $\begin{array}{l}\text { ai- } C_{15: 0} \\
\quad \text { i- } C_{16: 0}\end{array}$ \\
\hline $\begin{array}{l}\text { Major } \\
\text { menaquinone(s) }\end{array}$ & $12,13,14$ & $12,13,14$ & 12 & 11 & 11,12 & $10,11,12$ & 10,11 \\
\hline $\begin{array}{l}\text { DNA G }+\mathrm{C} \\
\text { content }(\mathrm{mol} \%)\end{array}$ & 68.3 & $67.1-68.8$ & 71.1 & 61.0 & 62.0 & $64.0-73.4$ & 58.7 \\
\hline
\end{tabular}

${ }^{\star}$ DAB, Diaminobutyric acid; Lys, lysine; Orn, ornithine.

$(21 \%)$. The DNA $\mathrm{G}+\mathrm{C}$ content of strain $\mathrm{CW}^{\mathrm{T}}$ was $68.3 \pm 0.4 \mathrm{~mol} \%$, within the range of values reported for members of the family Microbacteriaceae.

The taxonomic relationship between strain $\mathrm{CW}^{\mathrm{T}}$ and the type strains of Microcella putealis, Microcella alkaliphila and Yonghaparkia alkaliphila was further examined based on DNA-DNA hybridization experiments. Genomic DNADNA relatedness was determined by using a membrane filter technique with DIG High Prime DNA Labelling and Detection Starter kit II (Roche Applied Science) according to the manufacturer's instructions and Lee et al. (2003).

Strain $\mathrm{CW}^{\mathrm{T}}$ shared 22, 29 and $16 \%$ DNA-DNA relatedness with Microcella putealis KCTC $19625^{\mathrm{T}}$, Microcella alkaliphila KCTC $19624^{\mathrm{T}}$ and Yonghaparkia alkaliphila KCTC $19126^{\mathrm{T}}$, respectively, demonstrating that it represents a novel species (Wayne et al., 1987).

Phylogenetic, genomic, chemotaxonomic and phenotypic data clearly indicate that strain $\mathrm{CW}^{\mathrm{T}}$ represents a novel species of a new genus within the family Microbacteriaceae, for which the name Chryseoglobus frigidaquae gen. nov., sp. nov. is proposed.

\section{Description of Chryseoglobus gen. nov.}

Chryseoglobus (Chry.se.o.glo'bus. Gr. adj. chryseos golden; L. masc. n. globus ball; N.L. masc. n. Chryseoglobus yellow ball).
Cells are Gram-positive, aerobic, non-sporulating, motile, catalase-positive, oxidase-negative, pleomorphic, short, slender rods. Bulbous protuberances are formed at the ends or in the middle of cells. The cell-wall peptidoglycan contains D-lysine as a diamino acid. The glycan moiety of the peptidoglycan contains acetyl residues. The respiratory quinones are MK-12, MK-13 and MK-14. Mycolic acids are not present. Diphosphatidylglycerol, phosphatidylglycerol and an unknown glycolipid are detected in polar lipid extracts. Branched saturated components are the predominant fatty acids. The type species is Chryseoglobus frigidaquae.

\section{Description of Chryseoglobus frigidaquae sp. nov.}

Chryseoglobus frigidaquae (fri.gi.da'quae. L. adj. frigidus cold; L. fem. n. aqua water; N.L. gen. n. frigidaquae from/of cold water, as the type strain was isolated from a watercooling system).

Has the following characteristics in addition to those given for the genus. Colonies on TSA agar are yellow, raised, entire, translucent, circular, smooth and approximately $1 \mathrm{~mm}$ in diameter after 3 days at $30{ }^{\circ} \mathrm{C}(\mathrm{pH} \mathrm{7})$. Produces diffusible yellow pigments. Grows well on TSA and NA. Growth occurs in the presence of $0-3 \%(\mathrm{w} / \mathrm{v}) \mathrm{NaCl}$ (optimum 0\%), at $\mathrm{pH}$ 6-11 (optimum $\mathrm{pH} 7-8$ ) and at $20-40{ }^{\circ} \mathrm{C}$ (optimum $30{ }^{\circ} \mathrm{C}$ ). Produces $\beta$-galactosidase, $\alpha$ - 
glucosidase, aesculin hydrolase and leucine arylamidase. Nitrate is not reduced. Does not produce lysine decarboxylase, ornithine decarboxylase, tryptophan deaminase, gelatinase, arginine dihydrolase, indole or urease. Does not produce alkaline phosphatase, esterase (C4), esterase lipase (C8), lipase (C14), valine arylamidase, cystine arylamidase, trypsin, $\alpha$-chymotrypsin, acid phosphatase, naphthol-ASBI-phosphohydrolase, $\alpha$-galactosidase, $\beta$-glucuronidase, $\beta$ glucosidase, $N$-acetyl- $\beta$-glycosaminidase, $\alpha$-mannosidase or $\alpha$-fucosidase. Utilizes L-arabinose, ribose and aesculin as sole carbon and energy sources, but not adonitol, glucose, mannose, mannitol, $\mathrm{N}$-acetylglucosamine, fructose, maltose, gluconate, caprate, adipate, malate, citrate, phenylacetate, glycerol, erythritol, D-arabinose, D-xylose, L-xylose, methyl $\beta$-D-xyloside, galactose, sorbose, rhamnose, dulcitol, inositol, sorbitol, methyl $\alpha$-D-mannoside, methyl $\alpha$-D-glucoside, amygdalin, arbutin, salicin, cellobiose, lactose, melibiose, sucrose, trehalose, inulin, melezitose, raffinose, starch, glycogen, xylitol, $\beta$-gentiobiose, turanose, D-lyxose, D-tagatose, D- or L-fucose, D- or L-arabitol, gluconate, 2-ketogluconate or 5-ketogluconate. Major fatty acids are iso- $\mathrm{C}_{16: 0}$, anteiso- $\mathrm{C}_{15: 0}$, iso- $\mathrm{C}_{14: 0}$ and $\mathrm{C}_{16: 0}$. The DNA $\mathrm{G}+\mathrm{C}$ content of the type strain is $68.3 \mathrm{~mol} \%$.

The type strain, $\mathrm{CW}^{\mathrm{T}}\left(=\mathrm{KCTC} 13142^{\mathrm{T}}=\mathrm{JCM} 14730^{\mathrm{T}}\right)$, was isolated from a water-cooling system at Gwangyang, Republic of Korea.

\section{Acknowledgements}

This research was supported by the 21C Frontier Microbial Genomics and Applications Center Program, Ministry of Education, Science \& Technology, Republic of Korea. We are indebted to Dr Brian Tindall and Dr Peter Schumann (Deutsche Sammlung von Mikroorganismen und Zellkulturen $\mathrm{GmbH}$, Braunschweig, Germany) for determining the quinone and peptidoglycan structure, respectively.

\section{References}

An, S. Y., Xiao, T. \& Yokota, A. (2008). Schumannella luteola gen. nov., sp. nov., a novel genus of the family Microbacteriaceae. J Gen Appl Microbiol 54, 253-258.

Bernardet, J.-F., Nakagawa, Y. \& Holmes, B. (2002). Proposed minimal standards for describing new taxa of the family Flavobacteriaceae and emended description of the family. Int J Syst Evol Microbiol 52, 1049-1070.

Chun, J. \& Goodfellow, M. (1995). A phylogenetic analysis of the genus Nocardia with 16S rRNA gene sequences. Int J Syst Bacteriol 45, 240-245.

Chun, J., Bae, K. S., Moon, E. Y., Jung, S. O., Lee, H. K. \& Kim, S. J. (2000). Nocardiopsis kunsanensis sp. nov., a moderately halophilic actinomycete isolated from a saltern. Int J Syst Evol Microbiol 50, 1909-1913.

CLSI (2003). Performance standards for antimicrobial disk susceptibility tests, 8th edn. Approved Standard M2-A8. Wayne, PA: Clinical and Laboratory Standards Institute.

Collins, M. D. \& Bradbury, J. F. (1992). The genera Agromyces, Aureobacterium, Clavibacter, Curtobacterium, and Microbacterium. In
The Prokaryotes, 2nd edn, pp. 1354-1368. Edited by A. Balows, H. G. Trüper, M. Dworkin, H. Harder \& K. H. Schleifer. Berlin: Springer.

Evtushenko, L. I., Dorofeeva, L. V., Subbotin, S. A., Cole, J. R. \& Tiedje, J. M. (2000). Leifsonia poae gen. nov., sp. nov., isolated from nematode galls on Poa annua, and reclassification of 'Corynebacterium aquaticum' Leifson 1962 as Leifsonia aquatica (ex Leifson 1962) gen. nov., nom. rev., comb. nov. and Clavibacter xyli Davis et al. 1984 with two subspecies as Leifsonia xyli (Davis et al. 1984) gen. nov., comb. nov. Int J Syst Evol Microbiol 50, 371-380.

Felsenstein, J. (1985). Confidence limits on phylogenies: an approach using the bootstrap. Evolution 39, 783-791.

Fitch, W. M. \& Margoliash, E. (1967). Construction of phylogenetic trees. Science 155, 279-284.

Gosink, J. J., Woese, C. R. \& Staley, J. T. (1998). Polaribacter gen. nov., with three new species, $P$. irgensii sp. nov., $P$. franzmannii sp. nov. and $P$. filamentus sp. nov., gas vacuolate polar marine bacteria of the Cytophaga-Flavobacterium-Bacteroides group and reclassification of 'Flectobacillus glomeratus' as Polaribacter glomeratus comb. nov. Int J Syst Bacteriol 48, 223-235.

Han, S. K., Nedashkovskaya, O. I., Mikhailov, V. V., Kim, S. B. \& Bae, K. S. (2003). Salinibacterium amurskyense gen. nov., sp. nov., a novel genus of the family Microbacteriaceae from the marine environment. Int J Syst Evol Microbiol 53, 2061-2066.

Jones, D. \& Collins, M. D. (1986). Irregular, nonsporing Grampositive rods. In Bergey's Manual of Systematic Bacteriology, vol. 2, pp. 1261-1266. Edited by P. H. A. Sneath, N. S. Mair, M. E. Sharpe \& J. G. Holt. Baltimore: Williams \& Wilkins.

Jukes, T. H. \& Cantor, C. R. (1969). Evolution of protein molecules. In Mammalian Protein Metabolism, vol. 3, pp. 21-132. Edited by H. N. Munro. New York: Academic Press.

Kämpfer, P., Rainey, F. A., Andersson, M. A., Nurmiaho Lassila, E.-L., Ulrych, U., Busse, H.-J., Weiss, N., Mikkola, R. \& Salkinoja-Salonen, M. (2000). Frigoribacterium faeni gen. nov., sp. nov., a novel psychrophilic genus of the family Microbacteriaceae. Int J Syst Evol Microbiol 50, 355363.

Kovács, N. (1956). Identification of Pseudomonas pyocyanea by the oxidase reaction. Nature 178, 703.

Kroppenstedt, R. M. (1985). Fatty acid and menaquinone analysis of actinomycetes and related organisms. In Chemical Methods in Bacterial Systematics (Society for Applied Bacteriology Technical Series vol. 20), pp. 173-199. Edited by M. Goodfellow \& D. E. Minnikin. New York: Academic Press.

Lee, J.-S., Lee, K. C., Pyun, Y.-R. \& Bae, K. S. (2003). Arthrobacter koreensis sp. nov., a novel alkalitolerant bacterium from soil. Int J Syst Evol Microbiol 53, 1277-1280.

MacKenzie, S. L. (1987). Gas chromatographic analysis of amino acids as the $N$-heptafluorobutyryl isobutyl esters. J Assoc Off Anal Chem 70, 151-160.

Mandel, M., Igambi, L., Bergendahl, J., Dodson, M. L. \& Scheltgen, E. (1970). Correlation of melting temperature and cesium chloride buoyant density of bacterial deoxyribonucleic acid. J Bacteriol 101, 333-338.

Männistö, M. K., Schumann, P., Rainey, F. A., Kämpfer, P., Tsitko, I., Tiirola, M. A. \& Salkinoja-Salonen, M. S. (2000). Subtercola boreus gen. nov., sp. nov. and Subtercola frigoramans sp. nov., two new psychrophilic actinobacteria isolated from boreal groundwater. Int $J$ Syst Evol Microbiol 50, 1731-1739.

Marmur, J. \& Doty, P. (1962). Determination of the base composition of deoxyribonucleic acid from its thermal denaturation temperature. J Mol Biol 5, 109-118.

MIDI (1999). Sherlock Microbial Identification System Operating Manual, version 3.0. Newark, DE: MIDI, Inc. 
Minnikin, D. E., O’Donnell, A. G., Goodfellow, M., Alderson, G., Athalye, M., Schaal, A. \& Parlett, J. H. (1984). An integrated procedure for the extraction of bacterial isoprenoid quinones and polar lipids. J Microbiol Methods 2, 233-241.

Park, Y.-H., Suzuki, K., Yim, D. G., Lee, K. C., Kim, E., Yoon, J., Kim, S., Kho, Y. H., Goodfellow, M. \& Komagata, K. (1993). Suprageneric classification of peptidoglycan group $\mathrm{B}$ actinomycetes by nucleotide sequencing of 5 S ribosomal RNA. Antonie van Leeuwenhoek 64, 307-313.

Reddy, G. S. N., Prabagaran, S. R. \& Shivaji, S. (2008). Leifsonia pindariensis sp. nov., isolated from the Pindari glacier of the Indian Himalayas, and emended description of the genus Leifsonia. Int J Syst Evol Microbiol 58, 2229-2234.

Saitou, N. \& Nei, M. (1987). The neighbor-joining method: a new method for reconstructing phylogenetic trees. Mol Biol Evol 4, 406425.

Schleifer, K. H. (1985). Analysis of the chemical composition and primary structure of murein. Methods Microbiol 18, 123-156.

Schleifer, K. H. \& Kandler, O. (1972). Peptidoglycan types of bacterial cell walls and their taxonomic implications. Bacteriol Rev 36, 407-477.

Sheridan, P. P., Loveland-Curtze, J., Miteva, V. I. \& Brenchley, J. E. (2003). Rhodoglobus vestalii gen. nov., sp. nov., a novel psychrophilic organism isolated from an Antarctic Dry Valley lake. Int J Syst Evol Microbiol 53, 985-994.

Skerman, V. B. D. (1967). A Guide to the Identification of the Genera of Bacteria, 2nd edn. Baltimore: Williams \& Wilkins.

Stackebrandt, E., Rainey, F. A. \& Ward-Rainey, N. L. (1997). Proposal for a new hierarchic classification system, Actinobacteria classis nov. Int J Syst Bacteriol 47, 479-491.

Suzuki, K., Sasaki, J., Uramoto, M., Nakase, T. \& Komagata, K. (1997). Cryobacterium psychrophilum gen. nov., sp. nov., nom. rev., comb. nov., an obligately psychrophilic actinomycete to accommod- ate "Curtobacterium psychrophilum" Inoue and Komagata 1976. Int J Syst Bacteriol 47, 474-478.

Swofford, D. L. (1998). Phylogenetic analysis using parsimony (PAUP), version 4. Sunderland, MA: Sinauer Associates.

Tiago, I., Pires, C., Mendes, V., Morais, P. V., da Costa, M. \& Veríssimo, A. (2005). Microcella putealis gen. nov., sp. nov., a Grampositive alkaliphilic bacterium isolated from a nonsaline alkaline groundwater. Syst Appl Microbiol 28, 479-487.

Tiago, I., Morais, P. V., da Costa, M. S. \& Veríssimo, A. (2006). Microcella alkaliphila sp. nov., a novel member of the family Microbacteriaceae isolated from a non-saline alkaline groundwater, and emended description of the genus Microcella. Int J Syst Evol Microbiol 56, 2313-2316.

Uchida, K., Kudo, T., Suzuki, K. \& Nakase, T. (1999). A new rapid method of glycolate test by diethyl ether extraction, which is applicable to a small amount of bacterial cells of less than one milligram. J Gen Appl Microbiol 45, 49-56.

Vaz-Moreira, I., Nobre, M. F., Ferreira, A. C. S., Schumann, P., Nunes, O. C. \& Manaia, C. M. (2008). Humibacter albus gen. nov., sp. nov., isolated from sewage sludge compost. Int J Syst Evol Microbiol 58, 1014-1018.

Wayne, L. G., Brenner, D. J., Colwell, R. R., Grimont, P. A. D., Kandler, O., Krichevsky, M. I., Moore, L. H., Moore, W. E. C., Murray, R. G. E. \& other authors (1987). International Committee on Systematic Bacteriology. Report of the ad hoc committee on reconciliation of approaches to bacterial systematics. Int J Syst Bacteriol 37, 463464.

Yoon, J.-H., Kang, S.-J., Schumann, P. \& Oh, T.-K. (2006). Yonghaparkia alkaliphila gen. nov., sp. nov., a novel member of the family Microbacteriaceae isolated from an alkaline soil. Int J Syst Evol Microbiol 56, 2415-2420. 